\title{
The influence of colostral immunoglobulin concentration in heifer calves' serum on their health and growth
}

\author{
K. Furman-Fratczak, A. Rzasa, ${ }^{1}$ and T. Stefaniak \\ Department of Immunology, Pathophysiology and Veterinary Prevention, Wroclaw University of Environmental and Life Sciences, ul. Norwida 31 , \\ 50-375 Wroclaw, Poland
}

\begin{abstract}
The aim of this study was to determine factors affecting passive transfer in heifer calves born within $1 \mathrm{yr}$ and how passive transfer influences rearing to the period of first insemination under commercial dairy farm conditions. Calves were divided into 4 groups based on serum immunoglobulin concentrations at 30 to $60 \mathrm{~h}$ of life $(<5,5-10,10-15$, and $>15 \mathrm{~g} / \mathrm{L}$, respectively in groups 1 to 4). Calving ease, dam parity, calf body weight at birth, calf vitality, quality of colostrum, time and volume of first colostrum fed, morbidity rate and intensity of illness, growth rate, and age and efficiency of first insemination service were recorded. Plasma fibrinogen, and serum $\gamma$-globulin, $\operatorname{IgG}_{1}, \operatorname{IgG}_{2}$, IgM, and haptoglobin were estimated at 30 to $60 \mathrm{~h}$ and again at 21 to 28 $\mathrm{d}$ of life. Additionally, the immunoglobulin index $\left(\mathrm{I}_{\mathrm{Ig} 3-4}\right)$ was calculated. The main cause of FPT and PFPT in the calves was poor vitality associated with dystocia and low volume of ingested colostrum. The calves born to primiparous cows were more endangered than those born to multiparous cows. The morbidity and intensity of disease course were lowest in heifer calves with serum Ig concentration exceeding $10 \mathrm{~g} / \mathrm{L}$ at 30 to $60 \mathrm{~h}$ of life; these calves did not become ill before $\mathrm{d} 14$ of life. Calves with $>15 \mathrm{~g} / \mathrm{L} \gamma$-globulin in serum avoided respiratory tract infections. The immunoglobulin index was lowest (0.61) in calves from group 4 and highest in calves from groups 1 and 2 (1.44 and 0.88, respectively). The suitability of this index as well as haptoglobin determination was confirmed in prediction of morbidity risk and disease intensity in growing heifer calves. Heifers with serum $\gamma$-globulin levels $>10 \mathrm{~g} / \mathrm{L}$ at 30 to $60 \mathrm{~h}$ of life showed better health status and reached body weights allowing first insemination sooner.
\end{abstract}

Key words: calf, colostral immunity, dairy heifer, health status

Received March 11, 2010.

Accepted August 1, 2011.

${ }^{1}$ Corresponding author: anna.rzasa@up.wroc.pl

\section{INTRODUCTION}

The reduction in survival of dairy cows and the need to maintain a herd's reproduction level are associated with the effects of rearing heifer calves and their health (Campbell et al., 2007). The exploitation of cows for milk under large-farm conditions causes the common early breaking of the natural cow-calf contact. Feeding colostrum to calves is done by hand and entails time restrictions and reliable supervision (Petrie, 1984; McGuirk and Collins, 2004; Jaster, 2005). Despite increasing knowledge about factors that may limit the efficiency of the passive transfer of immunity, failure of passive transfer (FPT) occurs in a considerable portion of newborn dairy calves in Poland and other countries (Furman-Fratczak et al., 2005; Swan et al., 2007; Beam et al., 2009). An insufficient level of colostral immunity increases the susceptibility of calves to alimentary and respiratory tract infections and the risk of death in the first weeks of life (Wells et al., 1996; Donovan et al., 1998). Diarrhea and perinatal mortality are the main causes of death of calves up to d 14 of age (BrunningFann and Kaneene, 1992; Sivula et al., 1996). Moreover, calves that survive diarrhea before d 14 of life were more susceptible to respiratory tract infections in the ensuing period (Curtis et al., 1988; Virtala et al., 1999; van der Fels-Klerx et al., 2001).

A high level of colostral immunoglobulins in the serum of calves improves not only their health and growth in the first weeks of life, but also their further use as cows (DeNise et al., 1989; Donovan et al., 1998; Jarmuz et al., 2001). The literature describes different levels of serum immunoglobulin concentrations in neonatal calves that protect against disease. At $24 \mathrm{~h}$ of life, a diagnosis of FPT in calves occurs when the serum Ig concentration is $<10 \mathrm{~g} / \mathrm{L}$ (Weaver et al., 2000; Swan et al., 2007; Beam et al., 2009). Higher Ig levels indicate proper maternal protection of calves. Moraes et al. (2000) estimated the level of passive transfer in calves using a turbidity test and established that FPT occurs in calves with a serum Ig concentration $<5 \mathrm{~g} / \mathrm{L}$. In contrast to research in foals, partial failure of passive transfer (PFPT) is rarely described in calves and is 
likely underestimated in practice. Basoglu et al. (1999) and Güngör et al. (2004) stated that after the period of passive transfer, $\mathrm{Ig}$ levels $<8 \mathrm{~g} / \mathrm{L}$ indicate $\mathrm{FPT}$ in calves and concentrations between 8 and $16 \mathrm{~g} / \mathrm{L}$ indicate PFPT. In properly protected calves, serum Ig levels exceeded $16 \mathrm{~g} / \mathrm{L}$. The level of risk differs in calves with FPT and PFPT and influences the efficiency of treatment. In our own study, the following classification of calves was made: FPT $=$ serum $\mathrm{Ig}<5 \mathrm{~g} / \mathrm{L}$, PFPT $=5$ to $10 \mathrm{~g} / \mathrm{L}$, good protection $=10-15 \mathrm{~g} / \mathrm{L}$, and very good protection $=>15 \mathrm{~g} / \mathrm{L}$ (Furman-Fratczak et al., 2005).

Early detection of health disturbances in calves on dairy farms is difficult because of the large number of individuals and the group-keeping system (Tourlomoussis et al., 2004). An attractive diagnostic tool seems to be determining levels of acute phase proteins (APP), which increase in response to infectious and noninfectious inflammatory processes. Especially useful APP in cattle are haptoglobin $(\mathbf{H p})$, fibrinogen $(\mathbf{F b})$, and serum amyloid A (Horadagoda et al., 1999; Ganheim et al., 2003; Jawor et al., 2008). In healthy cattle, Hp is not detected in about $50 \%$ of individuals and in the remaining $50 \%$, its serum level is $<0.1 \mathrm{~g} / \mathrm{L}$. The normal plasma $\mathrm{Fb}$ concentration is stable in cattle and does not exceed 3 to $7 \mathrm{~g} / \mathrm{L}$ (Eckersall and Conner, 1988).

The weight gain of calves and heifers should be maintained at a level that enables first insemination at around 15 mo. Optimal weight gain allows early calving and reduces the costs of rearing heifers (Hoffman and Funk, 1992; Macdonald et al., 2007).

The aim of this study was to determine factors affecting passive transfer in heifer calves and how it influences rearing to the period of first insemination under commercial dairy farm conditions.

\section{MATERIALS AND METHODS}

\section{Animals and Treatments}

The study was carried out on a dairy farm of 400 cows of the Polish Holstein-Friesian black and white breed. One hundred seventy-five heifer calves born during $1 \mathrm{yr}$ were observed from birth to the confirmation of first pregnancy. Bull calves were sold within the first 2 wk of life. Immediately after birth, the calves were placed in individual straw-bedded boxes and kept there for 2 wk. Newborn calves were handled and hand-fed colostrum by staff according to the farm's own procedures. The dam's first colostrum was given by artificial nipple when the calf made its first efforts to stand. Subsequent colostrum feedings depended on the farm's milking times, which were at 0600 and $1500 \mathrm{~h}$. Newborn calves were injected 2 times subcutaneously (at 2 and $14 \mathrm{~d}$ of life) with $100 \mathrm{~mL}$ of serum obtained from 10 cows of the same farm immunized with Histophilus somni vaccine (Pro Animali, Wroclaw, Poland). The day after the last serum injection, the calves were moved to a calf barn into pens for 12 individuals. The calves were dehorned between wk 8 and 10 of life. In the fifth month of life, heifer calves were selected according to weight and moved to the next calf barn into pens for 20 individuals.

At the age of $6 \mathrm{mo}$ and BW of $200 \mathrm{~kg}$, the heifers were moved to the heifer barn. Before being moved, they were dewormed using ivermectin (Vetoquinol, Gorzow Wielkopolski, Poland) and vaccinated twice against dermatomycosis (Bovitrichovac, Biowet $\mathrm{Pu}$ lawy, Poland). The heifer barn was divided into 3 parts: animals were kept in the first part until 11 mo of age and in the second until 15 mo of age and $380 \mathrm{~kg}$ of BW; in the third part they underwent AI. Insemination of the heifers was performed at the first detected estrus. Pregnancy was detected about $30 \mathrm{~d}$ after insemination.

Immediately after birth, the vitality of the calves was estimated on a scale of $\mathrm{V}_{0}$ to $\mathrm{V}_{3}$ according to Szenci (1982; $\mathrm{V}_{0}=$ toneless, head drooping, limbs extended, cardiac activity absent; $\mathrm{V}_{1}=$ toneless, head drooping, limbs extended, cardiac activity present; $\mathrm{V}_{2}=$ low tonicity, abdominal recumbency with head requiring support, reduced number and intensity of reflectoric movements; $\mathrm{V}_{3}=$ normal tonicity, head erected, normal reflectoric movements) and calves were weighed. Stillborn calves $\left(V_{0}\right)$ were excluded from the study. Data on cow age (primiparous or multiparous) and hour of birth were recorded. Calving ease was estimated on a scale of 1 to 3 ( 1 = natural, easy, $2=$ pulled by farm staff, $3=$ complicated, with veterinarian intervention).

The quality of the first colostrum was determined based on organoleptic characteristics (including color and smell) on a scale of 1 to $4(1=$ normal color and smell, $2=$ normal colostrum with blood traces, $3=$ colostrum with inflammatory changes, $4=$ watery, pathological secretion). The density of the first colostrum was determined by a colostrometer (Pro Animali), and the immunoglobulin concentration was calculated based on a table relating colostrum density to Ig concentration. Based on colostrum density and Ig concentration, the colostrum was qualified as bad $(<39 \mathrm{~g}$ of $\mathrm{Ig} / \mathrm{L})$, passing $(42-77 \mathrm{~g}$ of $\mathrm{Ig} / \mathrm{L})$, good $(80-118 \mathrm{~g}$ of $\mathrm{Ig} / \mathrm{L})$, or very good $(>121 \mathrm{~g}$ of $\mathrm{Ig} / \mathrm{L})$. Calves were fed their mothers' colostrum until d 3 of life. The volume and hour of the first colostrum intake were recorded.

Jugular vein blood samples were taken from the calves twice: between 30 and $60 \mathrm{~h}$ of life (mean: $35.5 \mathrm{~h}$ ) and between 21 and $28 \mathrm{~d}$ of life (mean: $25 \mathrm{~d}$ ). Fibrinogen was measured in EDTA-containing blood samples. Blood serum was collected by centrifugation $(2,000 \times$ 
$g$ for 10 min at room temperature) and frozen $\left(-20^{\circ} \mathrm{C}\right)$ for subsequent analysis.

The calves were divided into 4 experimental groups based on serum $\gamma$-globulin concentration measured between 30 and $60 \mathrm{~h}$ of life: group $1=<5 \mathrm{~g} / \mathrm{L}, \mathrm{FPT}(\mathrm{n}=$ 22 ); group $2=\geq 5$ to $10 \mathrm{~g} / \mathrm{L}$, PFPT $(\mathrm{n}=83$ ); group 3 $=>10$ to $15 \mathrm{~g} / \mathrm{L}$, good protection $(\mathrm{n}=55)$; and group $4=>15 \mathrm{~g} / \mathrm{L}$, very good protection $(\mathrm{n}=15)$.

The number of veterinary treatments for diarrhea and respiratory tract infection was noted. Diarrhea cases were divided into (1) mild (lax feces); (2) moderate (multiple defecation of loose feces, signs of dehydration); and (3) severe (watery feces, strong dehydration, recumbency). Respiratory tract infections were divided into (1) mild (pathologic discharge from nostrils, sporadic cough); (2) moderate (pathological discharge from nostrils, frequent cough, poor disposition); and (3) severe (apparent dyspnea, recumbency, poor fettle).

During the rearing period, the heifers were weighed once a month. Their age and BW at the time of first insemination as well as the insemination index were determined. The criteria for allowing a heifer to the first insemination were age (minimum: $15 \mathrm{mo}$ ) and BW (minimum: $390 \mathrm{~kg}$ ).

\section{Analytical Procedures}

Fibrinogen was measured in whole-blood samples according to Millar et al. (1971). Total serum protein was determined using the Biuret method and its fractions (albumin, $\alpha-$, $\beta-, \gamma$-globulins) by paper electrophoresis. Haptoglobin concentration was determined by the guaiacol method according to Jones and Mould (1984). The concentrations of $\operatorname{IgG}_{1}, \operatorname{IgG}_{2}$, and IgM were measured by radial immunodiffusion (Mancini et al., 1964, modified by Gasowska and Stefaniak, 2003) in 10 randomly selected calves from each group. The index of total immunoglobulins $\left(\mathbf{I}_{\mathbf{I g} 3-4}\right)$ was calculated according to Nikolajczuk et al. (1994; the $\mathrm{I}_{\mathrm{Ig} 3-4}$ was calculated as the quotient of the serum Ig values in the third to fourth week of calves' lives divided by the Ig concentration in the forty-eighth hour of living; this index is a good measure of the adequacy of the calves' humoral postcolostral immunity against the present microbial threat).

\section{Statistical Analysis}

Treatment comparisons were made by ANOVA for a completely randomized design using the Statistica 8 statistical package (StatSoft Inc., Tulsa, OK). Differences between means were determined by the Duncan test when 3 groups were analyzed and by the Tukey test when 2 groups were analyzed. Pearson correlation coefficients for selected factors were calculated.

\section{RESULTS AND DISCUSSION}

\section{Delivery Course}

Under the conditions of the examined farm, the majority $(56 \%)$ of the cows calved in the afternoon and at night. Cows calved without human assistance in only $38 \%$ of cases. The proportion of multiparous cows in the respective experimental groups increased from $50 \%$ in group 1 to $80 \%$ in group 4 (Table 1). Moreover, the percentage of delivery courses of score 1 (natural, easy) increased from $27 \%$ in group 1 to $53 \%$ in group 4 . Most of the multiparous cows calved between 1200 and 1800 $\mathrm{h}$ (27.88\% of deliveries), and primiparous cows calved mainly between 2100 and $0300 \mathrm{~h}(34.37 \%)$. Because cows calved primarily during the day, the care routine of the staff was more efficient for multiparous cows than for primiparous cows. Because of the presence of all staff during the day, the supervision of delivery, early intervention, and the colostrum feedings were easier during the day than at night.

\section{Colostrum Quality}

The worst colostrum quality (score 4) was observed in groups 1 and 2 (9.1 and $1.2 \%$ of cases, respectively). The rate of blood presence in colostrum samples (score 2) was $4.5 \%$ in group 1 . In group 2 , colostrum with inflammatory signs (score 3) was found in 6\% of the samples. In groups 3 and 4, normal colostrum with a pleasant smell and proper color was found in $80 \%$ of the examined samples. In groups 3 and 4, no colostrum samples had scores 3 and 4 . It seems highly probable, therefore, that the poor passive transfer in the calves of groups 1 and 2 was caused in some cases by the colostrum used, which should generally be excluded from their feeding.

The mean colostrum Ig concentration was lowest in calves of group $2(63.2 \mathrm{~g} / \mathrm{L})$ and highest in calves of group $4(104.8 \mathrm{~g} / \mathrm{L})$. A common opinion is that colostrum appropriate for calves should contain at least 50 $\mathrm{g}$ of $\mathrm{Ig} / \mathrm{L}$ (Vasseur et al., 2009). Therefore, the mean colostrum Ig concentration in this herd $(79.48 \mathrm{~g} / \mathrm{L})$ could be considered good compared with that in other studies in Poland $(65.5 \mathrm{~g} / \mathrm{L}$ in Kinal et al., 2004; 63.0 $\mathrm{g} / \mathrm{L}$ in Zachwieja, 1995), as well as in other countries (59.0 g/L in Abel Francisco and Quigley, 1993; $48.8 \mathrm{~g} / \mathrm{L}$ in Kaske et al., 2005; $34.9 \mathrm{~g} / \mathrm{L}$ in Kehoe et al., 2007; and $48.2 \mathrm{~g} / \mathrm{L}$ in Pritchett et al., 1991). In groups 1 to 3 , the rates of colostrum evaluated as very good were 
Table 1. Origin, vitality, amounts of colostrum consumed, and BW of the calves (mean \pm SD for last 3 traits)

\begin{tabular}{lcccc}
\hline & \multicolumn{4}{c}{ Group $^{1}$} \\
\cline { 2 - 5 } Trait & 1 & 2 & 3 & 4 \\
\hline No. of cows (primiparous/multiparous) & $11 / 11$ & $33 / 50$ & $19 / 36$ & $3 / 12$ \\
Vitality score 1 (\%) & 4.54 & 1.2 & 0.00 & 0.00 \\
Vitality score 2 (\%) & 31.82 & 10.84 & 3.64 & 6.66 \\
Vitality score 3 (\%) & 63.64 & 87.95 & 96.36 & 93.33 \\
Volume of first colostrum consumed (L) & $1.36 \pm 0.52$ & $1.74 \pm 0.40$ & $1.85 \pm 0.38$ & $1.83 \pm 0.36$ \\
BW at birth (kg) & $39.7 \pm 5.9$ & $39.9 \pm 5.7$ & $39.9 \pm 6.3$ & $38.8 \pm 6.0$ \\
Colostrum consumed (\% of BW) & $3.5 \pm 1.25$ & $4.4 \pm 1.05$ & $4.7 \pm 1.08$ & $4.8 \pm 1.09$ \\
\hline
\end{tabular}

${ }^{1}$ Groups 1, 2, 3, and 4 had serum immunoglobulin concentrations at birth of $<5,5-10,10-15$, and $>15 \mathrm{~g} / \mathrm{L}$, respectively.

${ }^{2}$ Vitality score: $\mathrm{V}_{0}=$ stillborn, $\mathrm{V}_{1}=$ very poor disposition, $\mathrm{V}_{2}=$ poor disposition, and $\mathrm{V}_{3}=$ good disposition.

similar (about 9\%). In groups 1 and 2, in which the calves showed worse passive transfer, the rates of bad colostrum were higher (22.7 and $19.3 \%$, respectively). Although the rate of bad colostrum was higher in group 1 than in group 2, the rate of good colostrum was also higher in group 1 . Therefore, we identify dystocia and the high percentage of calves showing poor vitality at birth as the main causes of FPT in the calves of group 1.

\section{Colostrum Administration and Ig Course}

Despite the relatively high colostrum Ig concentration, over $90 \%$ of the calves had serum Ig concentrations $<15 \mathrm{~g} / \mathrm{L}$ at 30 to $60 \mathrm{~h}$ of life. A considerable number of the calves $(69.7 \%)$ were fed the first colostrum within $2 \mathrm{~h}$ after birth. In group 1, 59.1\% of the calves were given the first colostrum within $2 \mathrm{~h}$ of life, of which most were fed within 30 min after birth. In group 2, a slightly higher percentage $(69.9 \%)$ of calves were fed colostrum within $2 \mathrm{~h}$ of life. In the same group, the lowest percentage of calves $(33.7 \%)$ obtained colostrum within $30 \mathrm{~min}$. In group 3 , the highest percentage of calves $(12.7 \%)$ obtained first colostrum after $6 \mathrm{~h}$ of life. In group 4, $60.0 \%$ of the calves obtained the first colostrum within 30 min of life, $86.7 \%$ before $2 \mathrm{~h}$, and only $13.3 \%$ between 2 and 6 h of life. The ability of the calves to ingest colostrum early was associated with a vitality score of 3 in 63.6 to $96.4 \%$ of the calves in the respective groups (Table 1). Moreover, $88 \%$ of the newborn calves showed the highest degree of vitality. Immunoglobulin absorption is most efficient in the first few hours of life and declines rapidly after $12 \mathrm{~h}$ of life (Weaver et al., 2000) and it is recommended that calves be fed colostrum before $4 \mathrm{~h}$ of life (Beam et al., 2009).

At the first colostrum feeding, the calf should intake at least $2 \mathrm{~L}$ (about $5 \%$ of $\mathrm{BW}$ ), but that was not achieved in this herd (Table 1). In this study, the calves were fed $1.7 \mathrm{~L}$ of the first colostrum, which is more than that observed by Blaszkowska and Twardon (2005), where the calves consumed, on average, $1.3 \mathrm{~L}$ and individuals with FPT only 1.0 L. Vasseur et al. (2009) obtained different results: the calves ingested $3.3 \mathrm{~L}$, and in that study only $22 \%$ of them consumed less than $2 \mathrm{~L}$. The greatest individual differences in the volume of first colostrum fed occurred in the calves of group 1 (Table 1). Because the volume of voluntarily ingested colostrum depends on the willingness to suck (Vasseur et al., 2009), the relatively low amount observed in some calves was associated mostly with poor vitality. Early separation of calves from their dams and feeding an increased volume of colostrum within $6 \mathrm{~h}$ of birth is significantly associated with a reduced risk of FPT (Trotz-Williams et al., 2008).

The birth weights of the calves were very similar (mean: $39.8 \mathrm{~kg}$; Table 1), but significantly lower than in the study by Vasseur et al. (2009), where the mean birth weight of calves was $47.7 \pm 7.1 \mathrm{~kg}$.

At 30 to $60 \mathrm{~h}$ of life, highly significant differences were observed among the groups in $\gamma$-globulin serum concentration, upon which the grouping of the calves was based. Mean $\gamma$-globulin at 21 to $28 \mathrm{~d}$ of life decreased by $1.9 \mathrm{~g} / \mathrm{L}$ compared with the level at 30 to 60 $\mathrm{h}$ of life. In 10 calves that had $\gamma$-globulin concentrations $<5 \mathrm{~g} / \mathrm{L}$ (group 1), the sum of $\operatorname{IgG}_{1}, \operatorname{IgG}_{2}$, and $\operatorname{IgM}$, determined using radial immunodiffusion, was $8 \mathrm{~g} / \mathrm{L}$. In groups 2,3 , and 4 , the sum of $\operatorname{IgG}_{1}, \operatorname{IgG}_{2}$, and $\operatorname{IgM}$ was $10.4,13.6$, and $14.9 \mathrm{~g} / \mathrm{L}$, respectively. In group 1 , increases in $\operatorname{IgG}_{1}$ and $\operatorname{IgG}_{2}$ were observed between the 2 sampling periods, but the IgM level remained almost unchanged. In group 2, we observed slight decreases in $\mathrm{IgG}_{1}$ and $\operatorname{IgM}$ but an increase in $\operatorname{IgG}_{2}$ (Table 2). The increase in $\mathrm{IgG}_{2}$ before wk 5 of life is a consequence of the immune reaction to early infection caused by inappropriate protection by colostral immunoglobulins. 
Table 2. Average $\gamma$-globulin and $\operatorname{IgG}_{1}, \mathrm{IgG}_{2}$, and $\operatorname{IgM}$ levels (mean $\pm \mathrm{SD} ; \mathrm{g} / \mathrm{L}$ ) in calves' serum and immunoglobulin index $\left(\mathrm{I}_{\mathrm{Ig} 3-4}\right)^{1}$ value

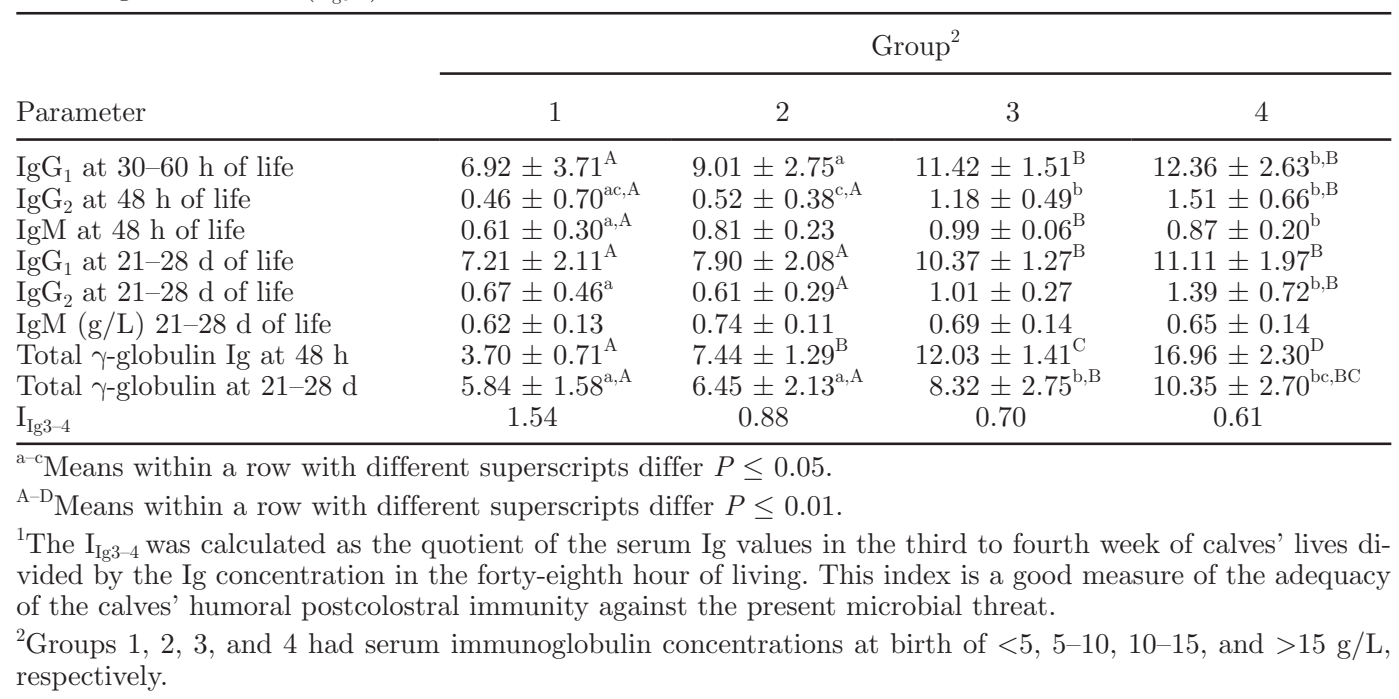

In groups 3 and 4 , decreases in all the examined immunoglobulins classes were found, and this may be considered a desirable result, indicating appropriate passive protection of the calves (Nikolajczuk et al., 1994).

The immunoglobulin index $\left(\mathrm{I}_{\mathrm{Ig} 3-4}\right)$ may be an interesting index for predicting the health of calves in future rearing stages and for evaluating the farm's prophylactic program (Table 2). The calculated mean $\mathrm{I}_{\mathrm{Ig} 3-4}$ was 0.9 for all the calves examined. According to the increase of colostrum protection in the respective groups, the $\mathrm{I}_{\mathrm{Ig} 3-4}$ value decreased from 1.54 (group 1) to 0.61 (group 4). This result must be considered disappointing compared with the optimum value of 0.4 proposed by Nikolajczuk et al. (1994). This high value may be a consequence of the fact that $60 \%$ of the calves (groups 1 and 2) were poorly protected by colostral immunity. The $\mathrm{I}_{\mathrm{Ig} 3-4}$ value calculated for the calves of group 4 (0.6) may be considered as only satisfactory. Similar results were described by Kinal et al. (2004). Based on $\mathrm{I}_{\mathrm{Ig} 3-4}$ values, as well as on immunoglobulin class changes, we conclude that most of the calves born in this herd were influenced by FPT or PFPT of immunity and therefore started an active immune response too early.
Some important correlations between the calves' passive immunity and selected rearing parameters were found (Table 3). Serum Ig concentration at 30 to $60 \mathrm{~h}$ of life was highly significantly correlated with that at d 21-28 of life. It is noteworthy that a highly significant negative correlation was found between the $\gamma$-globulin concentration at 30 to $60 \mathrm{~h}$ and $\mathrm{I}_{\mathrm{Ig} 3-4}$. The correlation coefficient between $\mathrm{I}_{\mathrm{Ig} 3-4}$ and gastrointestinal tract morbidity was statistically significant and indicates its high application value.

\section{APP Levels and Health Status}

The mean $\mathrm{Fb}$ concentration in the calves' blood plasma was initially $4.0 \mathrm{~g} / \mathrm{L}$ and increased to $4.8 \mathrm{~g} / \mathrm{L}$ at the second sampling (Table 4). At 30 to $60 \mathrm{~h}$ of life, all the calves of group 4 showed normal $\mathrm{Fb}$ concentrations and, in the other groups, only a few individuals had elevated levels (Ganheim et al., 2003). At 21 to 28 $\mathrm{d}$ of life, mean $\mathrm{Fb}$ levels were normal in all examined groups, and the rates of individuals showing elevated Fb levels were $18,12,3$, and $13 \%$ in groups $1,2,3$, and 4 , respectively.

Table 3. Correlation coefficients between selected parameters

\begin{tabular}{|c|c|c|c|c|c|c|c|c|}
\hline & Group & $\begin{array}{l}\text { Neonatal } \\
\text { diarrhea }\end{array}$ & $\begin{array}{c}\text { Diarrhea } \\
\text { in calf barn }\end{array}$ & Pneumonia & Ig $30-60 \mathrm{~h}$ & Ig $21-28 d$ & $\begin{array}{l}\mathrm{Ig} \\
\text { index }\end{array}$ & $\begin{array}{c}\text { Colostrum } \\
\text { Ig }\end{array}$ \\
\hline Group & 1 & & & & & & & \\
\hline Neonatal diarrhea & -0.350 & 1 & & & & & & \\
\hline Pneumonia & 0.075 & 0.577 & 0.000 & 1 & & & & \\
\hline Ig $30-60 \mathrm{~h}$ & $0.908^{* *}$ & -0.293 & -0.173 & -0.311 & 1 & & & \\
\hline Ig $21-28 \mathrm{~d}$ & $0.433^{* *}$ & 0.000 & -0.011 & -0.103 & $0.471^{*}$ & 1 & & \\
\hline
\end{tabular}

${ }^{*} P \leq 0.05 ;{ }^{* *} P \leq 0.01$. 
Table 4. Mean fibrinogen and haptoglobin levels (mean $\pm \mathrm{SD} ; \mathrm{g} / \mathrm{L}$ ) in the groups of calves

\begin{tabular}{|c|c|c|c|c|}
\hline \multirow[b]{2}{*}{ Parameter } & \multicolumn{4}{|c|}{ Group $^{1}$} \\
\hline & 1 & 2 & 3 & 4 \\
\hline \multicolumn{5}{|l|}{ Fibrinogen } \\
\hline $30-60 \mathrm{~h}$ of life & $4.32 \pm 1.56$ & $3.91 \pm 1.03$ & $4.24 \pm 1.29$ & $4.10 \pm 0.89$ \\
\hline $21-28 \mathrm{~d}$ of life & $5.47 \pm 1.80^{\mathrm{b}}$ & $4.79 \pm 1.78$ & $4.53 \pm 1.32^{\mathrm{a}}$ & $5.59 \pm 1.65^{\mathrm{b}}$ \\
\hline \multicolumn{5}{|l|}{ Haptoglobin } \\
\hline $30-60 \mathrm{~h}$ of life & $0.45 \pm 0.96$ & $0.21 \pm 0.38$ & $0.28 \pm 0.71$ & $0.26 \pm 0.41$ \\
\hline $21-28 \mathrm{~d}$ of life & $1.65 \pm 3.53^{\mathrm{b}}$ & $1.04 \pm 2.43$ & $0.39 \pm 1.42^{\mathrm{a}}$ & $0.34 \pm 0.89$ \\
\hline \multicolumn{5}{|l|}{ Haptoglobin $^{2}$} \\
\hline $30-60 \mathrm{~h}$ of life & $1.08 \pm 1.30$ & $0.61 \pm 0.45$ & $0.75 \pm 1.00$ & $0.56 \pm 0.44$ \\
\hline $21-28 \mathrm{~d}$ of life & $3.67 \pm 4.61$ & $3.18 \pm 3.38$ & $1.38 \pm 2.49$ & $0.95 \pm 1.37$ \\
\hline
\end{tabular}

Increased Hp concentration $(>0.1 \mathrm{~g} / \mathrm{L})$ was found in the serum of $32 \%$ of the calves at 30 to $60 \mathrm{~h}$ of life. Because $\mathrm{Hp}$ is not commonly detected in healthy cattle (Eckersall and Conner, 1988; Jawor et al., 2008), it was confusing that such a high percentage of calves showed elevated Hp levels at both 30 to $60 \mathrm{~h}$ and at 21 to $28 \mathrm{~d}$. This indicates a very unfavorable health status of the calves on the farm. The calves were in danger of inflammation from the first hours of life because it is known that about $10 \mathrm{~h}$ elapses between induction of inflammation and an Hp level >0.1 g/L (Hiss et al., 2004). The highest Hp levels, as well as the highest individual differences, occurred in the calves of group 1 (Table 4). At 21 to $28 \mathrm{~d}$ of life, $31 \%$ of the calves showed elevated Hp levels. In groups 1 and 2, the Hp levels increased by 28 and $4 \%$, respectively, and in groups 3 and 4, they decreased by 21 and $16 \%$, respectively. An increase in $\mathrm{Hp}$ concentration is commonly related to the intensity of an inflammatory reaction (Heegaard et al., 2000). In the groups less protected by colostral immunity, higher mean Hp levels and a higher rate of individuals showing elevated Hp concentration were detected. This observation agrees with the higher intensity and frequency of respiratory and gastrointestinal tract morbidity in the calves of groups 1 and 2 (Figure 1 ). In the calves better protected by colostrum, elevated levels of APP occurred rarely at 30 to $60 \mathrm{~h}$ and 21 to $28 \mathrm{~d}$ of life. The concentrations of $\mathrm{Hp}, \mathrm{Fb}, \gamma$-globulin, and Ig classes $\left(\mathrm{IgG}_{1}, \mathrm{IgG}_{2}\right.$, and $\left.\operatorname{IgM}\right)$ at 30 to $60 \mathrm{~h}$ and 21 to $28 \mathrm{~d}$ of life may be used as prediction indices of calf health during rearing.

During the observation period, gastrointestinal or respiratory tract disease occurred in more than half of the calves. Diarrhea occurred in $36.6 \%$ of calves and respiratory tract infections were observed less frequently $(13.7 \%)$. This is consistent with the results of Brun-
ning-Fann and Kaneene (1992), who found respiratory tract infections in 7 to $15 \%$ of calves. The incidence of disease differed among the groups, from $81.8 \%$ in group 1 to $26.7 \%$ in group 4 . Before moving calves to the calf barn, neonatal diarrhea was observed only in the calves of groups $1(18.2 \%)$ and $2(6.0 \%)$. No severe course was observed. After moving the calves to group pens in the calf barn, diarrhea cases occurred in calves of all groups (Figure 1). No mild course of respiratory tract infections was observed, but, surprisingly, no cases were detected in group 4 (with Ig level $>15 \mathrm{~g} / \mathrm{L}$ at $30-60 \mathrm{~h}$ of life).

\section{Growth Rate During Observations}

No significant differences in growth rate were found in the calves during the first 6 mo of life. The average growth rate in this period was $640 \mathrm{~g} / \mathrm{d}$. In the youngest group of heifers, statistically significant differences in growth rate occurred only in mo 8 between calves in groups $2,3,4$ and group $1(P \leq 0.01)$, which showed the lowest rate.

Between 12 and 15 mo of life, the heifers of group 4 showed the highest growth rate. Statistically significant differences were found between groups 3 and 4 at mo 14 and between groups 1 and 4 at mo 15 of life. The heifers of group 1 showed the lowest growth rate $(463 \mathrm{~g} / \mathrm{d})$ in mo 17 of life. It is noteworthy that the first heifer of group 1 was inseminated as late as age 18 mo. The mean age of the heifers at insemination was the lowest in group 4 (454 d), whereas the mean age on the farm was $471 \mathrm{~d}$. The difference between the heifers of groups 4 and 1 was $30 \mathrm{~d}(P \leq 0.01)$, that between groups 4 and 2 was $14 \mathrm{~d}$, and that between groups 4 and 3 was $21 \mathrm{~d}$ $(P \leq 0.05)$. The average BW at first insemination $(407$ $\mathrm{kg})$ was similar in all groups. 


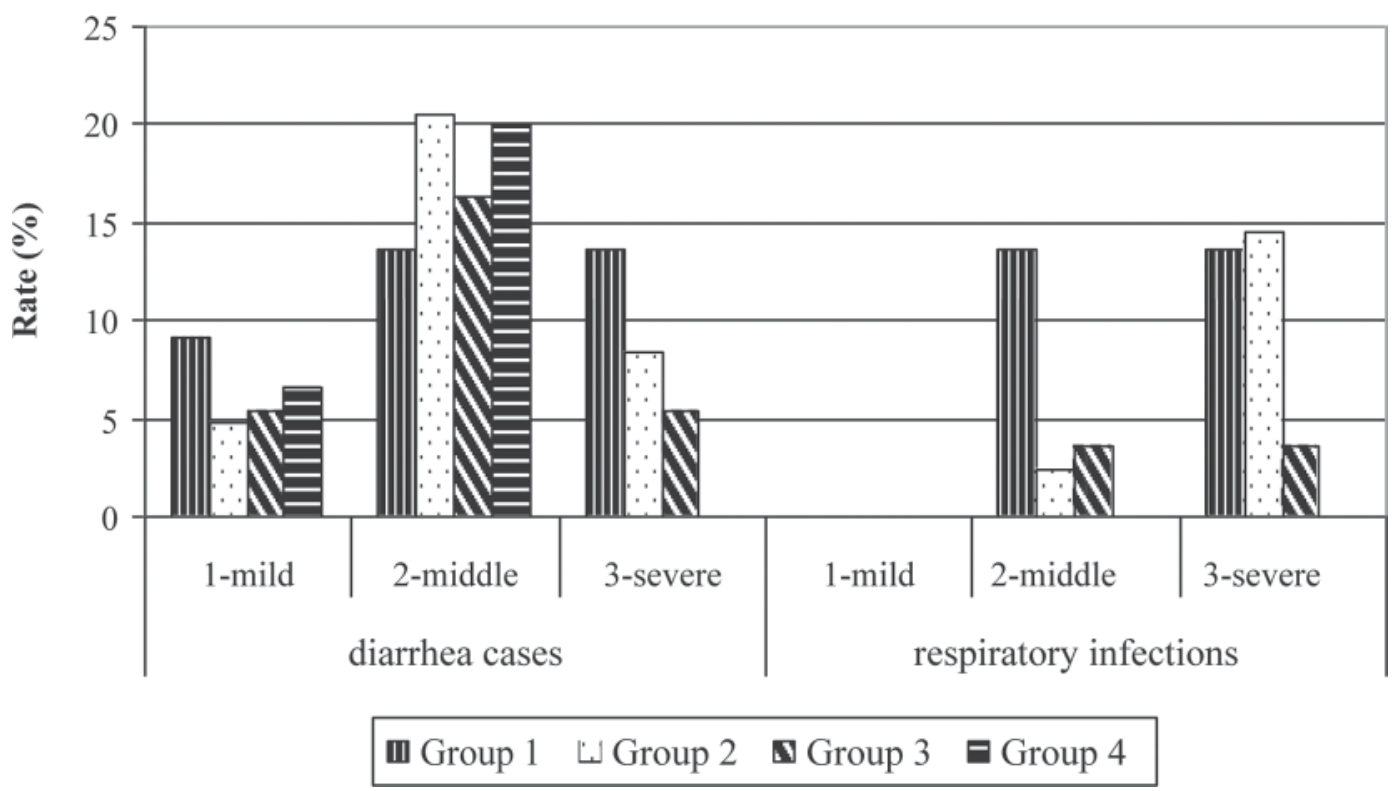

Figure 1. Rate and intensity of diseases in the groups of calves. Groups 1,2,3, and 4 had serum immunoglobulin concentrations at birth of $<5,5-10,10-15$, and $>15 \mathrm{~g} / \mathrm{L}$, respectively.

\section{CONCLUSIONS}

The main cause of FPT and PFPT in the calves was poor vitality associated with dystocia and a low volume of ingested colostrum. The calves born to primiparous cows were more endangered than those born to multiparous cows. The morbidity and intensity of disease course were the lowest in heifer calves with serum Ig concentration exceeding $10 \mathrm{~g} / \mathrm{L}$ at 30 to 60 $\mathrm{h}$ of life; these calves did not become ill before d 14 of life. Calves with serum $\gamma$-globulin $>15 \mathrm{~g} / \mathrm{L}$ avoided respiratory tract infections. Low risk of disease was confirmed by $\mathrm{I}_{\mathrm{Ig} 3-4}$ and APP values. Heifers with serum $\gamma$-globulin levels $>10 \mathrm{~g} / \mathrm{L}$ after passive transfer showed better health status and achieved BW allowing first insemination sooner.

\section{REFERENCES}

Abel Francisco, S. F., and J. D. Quigley. 1993. Serum immunoglobulin concentrations after feeding maternal colostrums or maternal colostrum plus colostral supplement to dairy calves. Am. J. Vet. Res. 54:1051-1054.

Basoglu, A., I. Camkerten, and M. Sevinç. 1999. Serum immunoglobulin concentrations in diarrheic calves and their measurement by single radial immunodiffusion. Isr. J. Vet. Med. 54:9-10.

Beam, A. L., J. E. Lombard, C. A. Kopral, L. P. Garber, A. L. Winter, J. A. Hicks, and J. L. Schlater. 2009. Prevalence of failure of passive transfer of immunity in newborn heifer calves and associated management practices on US dairy operations. J. Dairy Sci. 92:3973-3980

Blaszkowska, M., and J. Twardon. 2005. Level of $\operatorname{IgG}_{\mathrm{g}}, \operatorname{IgG}_{2}$ and $\operatorname{IgM}$ in colostrum and calves serum obtained during different periods following birth. Med. Welt 61:1308-1311. (in Polish)
Brunning-Fann, C. S., and J. B. Kaneene. 1992. Environmental and management risk factors associated with morbidity and mortality in perinatal and pre-weaning calves: A review from an epidemiological perspective. Vet. Bull. 62:399-413.

Campbell, J. M., L. E. Russell, J. D. Crenshaw, E. M. Weaver, S. Godden, J. D. Quigley, J. Coverdale, and H. Tyler. 2007. Impact of irradiation and immunoglobulin $\mathrm{G}$ concentration on absorption of protein and immunoglobulin $\mathrm{G}$ in calves fed colostrums replacer. J. Dairy Sci. 90:5726-5731.

Curtis, C. R., J. M. Scarlet, H. N. Erb, and M. E. White. 1988. Path model of individual-calf risk factor for calfhood morbidity and mortality in New York Holstein herds. Prev. Vet. Med. 6:43-62.

DeNise, S. K., J. D. Robinson, G. H. Stott, and D. V. Armstrong. 1989. Effects of passive immunity on subsequent production in dairy heifers. J. Dairy Sci. 72:552-554.

Donovan, G. A., I. R. Dohoo, D. M. Montgomery, and F. L. Bennet. 1998. Association between passive immunity and morbidity and mortality in dairy heifers in Florida, USA. Prev. Vet. Med. $33: 41-46$.

Eckersall, P. D., and J. G. Conner. 1988. Bovine and canine acute phase proteins. Vet. Res. Commun. 12:169-178.

Furman-Fratczak, K., A. Rzasa, and T. Stefaniak. 2005. Colostrum quality and calves' rearing results. Rocz. Nauk. Zootech. 2:281289. (in Polish)

Ganheim, C., C. Hulten, U. Carlsson, H. Kindahl, R. Niskanen, and K. P. Waller. 2003. The acute phase response in calves experimentally infected with bovine viral diarrhoea virus and/or Mannheimia haemolytica. J. Vet. Med. B Infect. Dis. Vet. Public Health 50:183-190.

Gasowska, A., and T. Stefaniak. 2003. Evaluation of oral yolk immunoglobulin ( $\mathrm{IgY}$ ) application in calves at the period of macromolecule absorption from the intestine. Folia Univ. Agric. Stetin. Zootec. 233:87-92.

Güngör, Ö., A. Bastan, and M. K. Erbie. 2004. The usefulness of the $\gamma$-glutamyltransferase activity and total proteinemia in serum for detection of the failure of immune passive transfer in neonatal calves. Rev. Med. Vet. (Toulouse) 155:27-30.

Heegaard, P. M. H., D. L. Godson, M. J. M. Toussaint, K. Tjørnehøj, L. E. Larsen, B. Viuff, and L. Rønsholt. 2000. The acute phase response of haptoglobin and serum amyloid A (SAA) in cattle un- 
dergoing experimental infection with bovine respiratory syncytial virus. Vet. Immunol. Immunopathol. 77:151-159.

Hiss, S., M. Mielenz, R. M. Bruckmaier, and H. Sauerwein. 2004. Haptoglobin concentrations in blood and milk after endotoxin challenge and quantification of mammary Hp mRNA expression. J. Dairy Sci. 87:3778-3784.

Hoffman, P. C., and D. A. Funk. 1992. Applied dynamics of dairy replacement growth and management. J. Dairy Sci. 75:2504-2516.

Horadagoda, N. U., K. M. G. Knox, H. A. Gibbs, S. W. J. Reid, A. Horadagoda, S. E. R. Edwards, and P. D. Eckersall. 1999. Acute phase proteins in cattle: Discrimination between acute and chronic inflammation. Vet. Rec. 144:437-441.

Jarmuz, W., I. Szelag, and R. Skrzypek. 2001. Relationship between concentration of blood serum immunoglobulins and growth rate in dairy heifers. Pr. Mat. Zoot. 59:93-101. (in Polish)

Jaster, E. H. 2005. Evaluation of quality, quantity, and timing of colostrum feeding on immunoglobulin $\mathrm{G}_{1}$ absorption in jersey calves. J. Dairy Sci. 88:296-302.

Jawor, P., S. Steiner, T. Stefaniak, W. Baumgartner, and A. Rzasa. 2008. Determination of selected acute phase proteins during the treatment of limb diseases in dairy cows. Vet. Med. (Praha) 53:173-183.

Jones, G. E., and D. L. Mould. 1984. Adaptation of the guaiacol (peroxidase) test for haptoglobins to a microtitration plate system. Res. Vet. Sci. 37:87-92.

Kaske, M., A. Werner, H. J. Schuberth, J. Rehage, and W. Kehler. 2005. Colostrum management in calves: Effects of drenching vs. bottle feeding. J. Anim. Physiol. Anim. Nutr. (Berl.) 89:151-157.

Kehoe, S. I., B. M. Jayarao, and A. J. Heinrichs. 2007. A survey of bovine colostrum composition and colostrum management practices on Pennsylvania dairy farms. J. Dairy Sci. 90:4108-4116.

Kinal, S., A. Rzasa, and A. Korniewicz. 2004. Mineral bioplex supplementation of diets for cows affects colostrums quality and immunoglobulin in calf blood serum. J. Anim. Feed Sci. 13(Suppl. 2):79-82.

Macdonald, K. A., L. R. McNaughton, G. A. Verkerk, J. W. Penno, L. J. Burton, D. P. Berry, P. J. S. Gore, J. A. S. Lancaster, and C. W. Holmes. 2007. A comparison of three strains of Holstein-Friesian cows grazed on pasture: Growth, development, and puberty. J. Dairy Sci. 90:3993-4003.

Mancini, G., J. P. Vaerman, A. O. Carbonara, and J. F. Heremans. 1964. A single radial diffusion method for the immunological quantitation of proteins. Pages 370-373 in Protides of the Biological Fluids. H. Peeters, ed. Elsevier Publishing Co., Amsterdam, the Netherlands.

McGuirk, S. M., and M. Collins. 2004. Managing the production, storage, and delivery of colostrum. Vet. Clin. North Am. Food Anim. Pract. 20:593-603.

Millar, H. R., J. G. Simpson, and A. L. Stalker. 1971. An evaluation of the heat precipitation method for plasma fibrinogen estimation. J. Clin. Pathol. 24:827-830.

Moraes, M. P., R. Weiblen, M. C. Rebelatto, and A. Moraes da Silva. 2000. Relationship between passive immunity and morbidity and weight gain in dairy cattle. Ciênc. Rural. Santa Maria 30:299-304.
Nikolajczuk, M., A. Chełmonska-Soyta, J. Mazur, W. Nowacki, T. Stefaniak, and J. Zielinski. 1994. The immunoglobulin index in the evaluation of the calves well being in the first weeks of life. Pages AW13-AW16 in Proc. 8th Int. Congr. Anim. Hyg. St. Paul, MN. International Society for Animal Hygiene.

Petrie, L. 1984. Maximising the absorption of colostral immunoglobulins in the newborn dairy calf. Vet. Rec. 114:157-163.

Pritchett, L. C., C. C. Gay, T. E. Besser, and D. D. Hancock. 1991. Management and production factors influencing immunoglobulin G1 concentration in colostrum from Holstein cows. J. Dairy Sci. 74:2336-2341.

Sivula, N. J., T. R. Ames, W. E. Marsh, and R. E. Werdin. 1996. Descriptive epidemiology of morbidity and mortality in Minnesota dairy heifer calves. Prev. Vet. Med. 27:155-171.

Swan, H., S. Godden, R. Bey, S. Wells, J. Fetrow, and H. ChesterJones. 2007. Passive transfer of immunoglobulin $\mathrm{G}$ and preweaning health in Holstein calves fed a commercial colostrums replacer. J. Dairy Sci. 90:3857-3866.

Szenci, O. 1982. Correlations between muscle tone and acid-base balance in newborn calves: Experimental substantiation of a simple new score system proposed for neonatal status diagnosis. Acta Vet. Acad. Sci. Hung. 30:79-84.

Tourlomoussis, P., P. D. Eckersall, M. M. Waterson, and S. Buncic. 2004. A comparison of acute phase protein measurements and meat inspection findings in cattle . Foodborne Pathog. Dis. 1:281-290.

Trotz-Williams, L. A., K. E. Leslie, and A. S. Peregrine. 2008. Passive immunity in Ontario dairy calves and investigation of its association with calf management practices. J. Dairy Sci. 91:3840-3849.

van der Fels-Klerx, H. J., J. T. Sørensen, A. W. Jalvingh, and R. B. M. Huirne. 2001. An economic model to calculate farm-specific losses due to bovine respiratory disease in dairy heifers. Prev. Vet. Med. 51:75-94.

Vasseur, E., J. Rushen, and A. M. de Passillé. 2009. Does a calf's motivation to ingest colostrum depend on time since birth, calf vigor, or provision of heat? J. Dairy Sci. 92:3915-3921.

Virtala, A. M. K., Y. T. Gröhn, G. D. Mechor, and H. N. Erb. 1999 The effect of maternally derived immunoglobulin $\mathrm{G}$ on the risk of respiratory disease in heifers during the first 3 months of life. Prev. Vet. Med. 39:25-37.

Weaver, D. M., J. W. Tyler, D. C. VanMetre, D. E. Hostetler, and G. M. Barrington. 2000. Passive transfer of colostral immunoglobulins in calves. J. Vet. Intern. Med. 14:569-577.

Wells, S. J., D. A. Dargatz, and S. L. Ott. 1996. Factors associated with mortality to 21 days of life in dairy heifers in the United States. Prev. Vet. Med. 29:9-19.

Zachwieja, A. 1995. The analysis of variability of cows' colostrum compositions and the level of protein fractions in their calves blood serum. Part I. The influence of herd, age of cows and their calving season. Zesz. Nauk. AR Wroc. Zoot. XL 271:156-175. (in Polish). 